\title{
Win TR-20 Application Using Statistical Approaches for Long Term Prediction of Peak Runoff Rates in Smaller Watersheds of Pakistan
} Jan Muhammad* and Gul Daraz Khan

Department of Water Management, The University of Agriculture Peshawar, Khyber Pakhtunkhwa, Pakistan

\begin{abstract}
Calibrated Win TR-20 model was validated and simulated to predict the peak runoff rates for 2, 5, 10, 25, 50 and 100 years for a small watershed area of $72 \mathrm{~km}^{2}$ in the southern region of Khyber Pakhtunkhwa of Pakistan. The catchment has a gauged spillway outlet at the downstream. The model was initially calibrated on the available known parameters from the grid survey and its derivatives, watershed physical features and other scales endorsed into the reservoir for monitoring. The calibrated model was tested and validated on physical data collected for duration of three months with a coefficient of determination of $98 \%$ among the observed and estimated runoff depths and peak runoff. After confirmation log-Pearson type III distribution was fitted to annual one day maximum rainfall upon which one day maximum rainfalls for $2,5,10,25,50$ and 100 years return periods were simulated as $50,80,105$, 144,180 and $223 \mathrm{~mm}$ respectively. Run off depths for the same one day maximum rainfall of given returns period were further simulated as $10.34,21.15,30.3,39.78$, and 84.03 and $53.14 \mathrm{~mm}$. Moreover the peak runoff rates for the return periods of $2,5,10,25,50$ and 100 years were predicted as $11.3,39.9,77.7,147.5,221.9$, and $320 \mathrm{~m}^{3} \mathrm{~s}^{-1}$. Hence it was concluded that Win TR-20 provided satisfactory simulation of rainfall and their resultant runoffs and peak runoff rates which can be confidently recommended for use in small watersheds in the specific region of Khyber Pakhtunkhwa.
\end{abstract}

Keywords: Watershed; Peak runoff; Win TR-20; Log-Pearson type III; Rainfall runoff relationships; One day maximum rainfall

\section{Introduction}

Analytically it is extremely difficult to convert an accounted amount of rainfall in an area into their runoff because it involves lot of factors related to soil, weather conditions and other unforeseen natural processes. However, making some assumptions, several methods have been introduced to predict runoff amount from rainfall with acceptable accuracy [1]. The Soil Conservation Service (SCS) now known as Natural Resources Conservation Service (NRCS) developed the TR20 computer model in 1964 for use in combined hydrologic studies of storm water [2]. Since its creation, it has been updated several times. With the last modification made in 2004 NRCS created a windows based model known as Win TR-20. Due to its simplicity Win TR-20 is the most widely used method for computing runoff volume and peak rate [3]. The TR-20 has been applied for storm runoff prediction in both agricultural $[4,5]$ and urban $[3,6]$ watersheds. The model was also used to calculate flood hydrographs in the Dreisam watershed in southwestern Germany [7]. Barfield et al. [8] modified the NRCS procedures of the TR-20 model to predict runoff volumes and peak discharges from a karst watershed. Cronshey and Woodward [9] revised the TR-20 model based on the approach in an alternative model named Ann AGNPS. Similarly, McCuen and Okunola [10] extended the TR-55 model, which is a simplification of the TR-20, to estimate peak discharge from micro-watersheds. In Korea, the TR-20 has tested to simulated runoff hydrographs in ungagged rural watershed [11]. These approaches require more field data and have focused on water quality estimation as well, the present study provides a sample case study to simulate storm hydrographs in a mixed land use watershed for the duration of 2, 5, 10,25, 50 and 100 years return periods which makes implication of Win TR-20 for the utilization in other watersheds for estimating runoffs.

\section{Materials and Methods}

The Win TR-20 uses SCS curve number and dimensionless unit hydrograph methods for storm runoff calculation. The SCS relationship for storm runoff [12] is

$$
\begin{aligned}
& Q=\frac{(P-0.2 S)^{2}}{P+0.8 S} \\
& S=\frac{25400}{C N}-254
\end{aligned}
$$

Where $\mathrm{Q}$ is accumulated runoff depth $(\mathrm{mm}), \mathrm{S}$ is Potential maximum retention $(\mathrm{mm}), \mathrm{P}$ is Accumulated rainfall depth $(\mathrm{mm})$ and $\mathrm{CN}$ is Curve Number. Time of Concentration $(\mathrm{Tc})$ was calculated with the following formula

$$
T c=\frac{L^{0.8}\left[\left(\frac{1000}{C N}\right)-9\right]^{0.7}}{\left[4407\left(S_{g}\right)^{0.5}\right]}
$$

Where $\mathrm{T}_{\mathrm{c}}$ is time of concentration (hrs), $\mathrm{L}$ is longest flow length $(\mathrm{m}), \mathrm{CN}$ is runoff curve number and $\mathrm{S}_{\mathrm{g}}$ is average watershed gradient in $\mathrm{m} / \mathrm{m}$.

\section{Rainfall analysis}

Long term (50 years) daily rainfall data from January 1961 to December 2010 for the study site obtained from Pakistan Meteorology Deportment was analyzed. Annual maximum daily rainfall values

*Corresponding author: Jan Muhammad, Department of Water Management, The University of Agriculture Peshawar, Khyber Pakhtunkhwa, Pakistan, Tel: +92331-2458341; E-mail: janmuhammad200@gmail.com

Received December 28, 2014; Accepted February 16, 2015; Published February 19,2015

Citation: Muhammad J, Khan GD (2015) Win TR-20 Application Using Statistical Approaches for Long Term Prediction of Peak Runoff Rates in Smaller Watersheds of Pakistan. Hydrol Current Res 6: 192. doi:10.4172/2157-7587.1000192

Copyright: (c) 2015 Muhammad J, et al. This is an open-access article distributed under the terms of the Creative Commons Attribution License, which permits unrestricted use, distribution, and reproduction in any medium, provided the original author and source are credited. 
picked from the whole data were analyzed for frequency distribution fitting using Easy Fit Software. Based on Chi-Square test, Easy Fit ranked Log Pearson III distribution as best fit distribution. Log-Pearson III was fitted on the data with the recommended procedure adopted by the United States Water Recourse Council 1967 for prediction of rainfall amounts for different return periods shown in Table 1.

\section{Prediction of peak runoff rate using Win TR-20 runoff model}

Win TR-20 Runoff model was used to predict peak runoff rate at outlet from its respective watersheds. Figure 1a shows map of the whole Kandar Dam watershed divided into five sub watersheds. All the required data related to the watersheds were provided to the model required. Figure $1 \mathrm{~b}$ shows the schematic diagram of the watersheds that have been generated by the Win TR- 20 model from the input data incorporated relating to the indicating watershed shown in Figure 1a. After the satisfaction on model understanding and acceptance of watersheds endorsement, the cross section rating, and structure and storm data were then provided as other inputs to the model.

\section{Results and Discussion}

\section{Model calibration, validation and simulation}

On the basis of available known parameters from grid survey and its derivatives, watershed physical features collected through field survey and other scales endorsed into the reservoirs and field daily dam record, the model was calibrated for the observed values of rainfall for generating peak discharges and volume of runoff. The grid survey of the whole reservoir including dam and its spillways and watershed area including waterways was performed and stage volume relationships were developed using SURFER computer software version 11. Runoff volume was estimated from the increase in storages of both the reservoirs and additional spillway overflow observed during storm. Applying the relation shown in equation 4 discharges from spillway was determined. To estimate spill over volume, discharges were multiplied with the observed duration. The estimated runoff depth was calculated by dividing the total cumulated volume over the whole watershed area.

$$
Q=C * L^{*} H^{3 / 2}
$$

Where $\mathrm{C}$ is $3.2, \mathrm{~L}$ is length of spillway $(27.3 \mathrm{~m})$ and $\mathrm{H}(\mathrm{m})$ is the head established by storm discharge.

The model was validated on three months (Jun, July and August of 2013) data with thirteen events of rainfall occurred. Out of all events six generated the runoff. Even a rainfall event for 24 hours from a $30 \mathrm{~mm}$ rainfall did not generate any runoff to be added to the reservoir. The successful events of runoff were found satisfactory for $95 \%$ confidence intervals (Figures 2 and 3 with an $\mathrm{R}^{2}$ of 0.9833 ). Hence Figure 2 shows successful validation of the model operation. After further success, model was then simulated for prediction of runoff for different returned periods of 2, 5, 10, 25, 50 and 100 years.

\section{Prediction of peak runoff}

Table 2 shows simulated runoffs and the expected peak discharges at the exit of the watershed for the required return periods. Predicted peak runoff for the return periods of 2, 5, 10, 25, 50 and 100 years estimated are $11.3,39.9,77.7,147.5,221.9$ and $320.0 \mathrm{~m}^{3} \mathrm{~s}^{-1}$ respectively. Furthermore the expected runoff depths for the given return periods are $5,17,32,57,84$ and $119 \mathrm{~mm}$.

Figure 3 shows the predicted hydrographs generated through Win TR-20 for the return periods of 2, 5, 10, 25, 50 and 100 years. This indicated that when both reservoirs are full then runoff at exit spillway will start after 8 hours (minimum response time) of the rainfall for the 100 years return period storm (Figure 4). However the spillway starts after 13 hours (maximum response time) for 2 years return period storm. The flood will reach the peak after 17 hours (longest time among the hydrographs) for 2 years return periods and will be at peak after 14 (shortest time among the hydrographs) for 100 years return period storm. The total storm length will be 27 hours (longest) for 100 years return period which will reach in 16 hours (shortest) for 2 years return period storm.

\begin{tabular}{|c|c|c|c|c|c|c|}
\hline Return period (years) & 2 & 5 & 10 & 25 & 50 & 100 \\
\hline Rainfall $(\mathrm{mm})$ & 50 & 80 & 105 & 144 & 180 & 223 \\
\hline
\end{tabular}

Table 1: Rainfall amount and their return period.

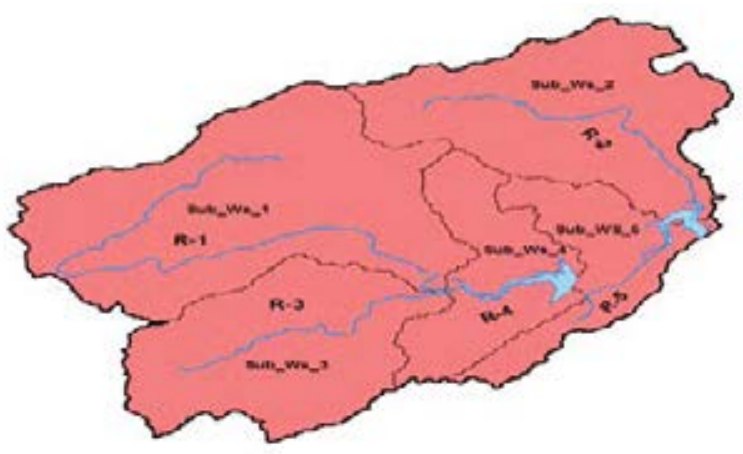

Figure 1a: Map of Sub-Watersheds along with their Reaches.

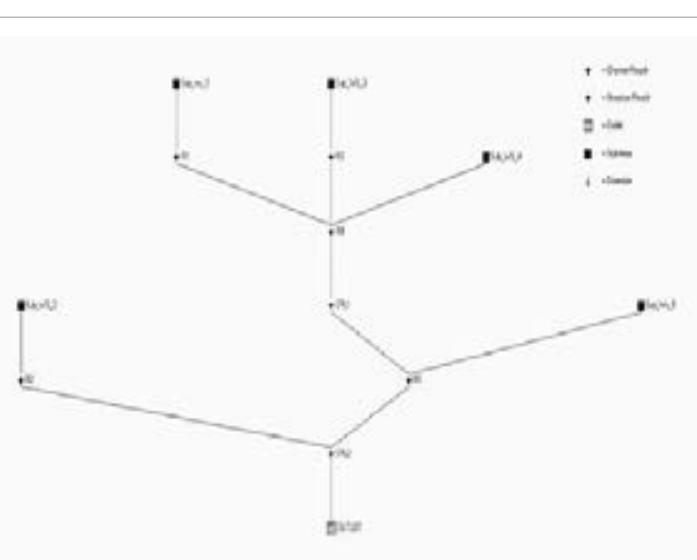

Figure 1b: Watershed Schematic Diagrams Developed by Win TR-20 Model.

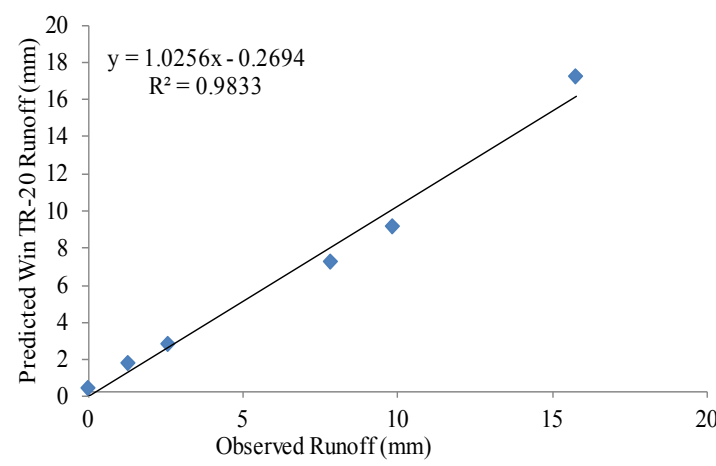

Figure 2: Observed vs Win TR-20 predicted runoff depths. 
Citation: Muhammad J, Khan GD (2015) Win TR-20 Application Using Statistical Approaches for Long Term Prediction of Peak Runoff Rates in Smaller Watersheds of Pakistan. Hydrol Current Res 6: 192. doi:10.4172/2157-7587.1000192

Page 3 of 3

\begin{tabular}{|c|c|c|c|c|c|c|}
\hline Return periods (years) & 2 & 5 & 10 & 25 & 50 & 100 \\
\hline Rainfall $(\mathrm{mm})$ & 50 & 80 & 105 & 144 & 180 & 223 \\
\hline Runoff $(\mathrm{mm})$ & 5 & 17 & 32 & 57 & 84 & 119 \\
\hline Peak Discharge $(\mathrm{m} 3 / \mathrm{s})$ & 11.3 & 39.9 & 77.7 & 147.5 & 221.9 & 320.0 \\
\hline
\end{tabular}

Table 2: Predicted peak runoff rates and discharges at outlet.

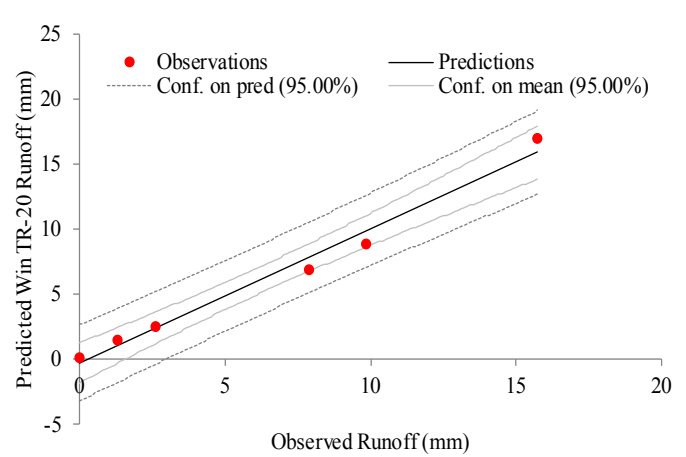

Figure 3: Win TR-20 model prediction vs. confidence intervals of $95 \%(5 \%$ Error) for observed runoff depths.

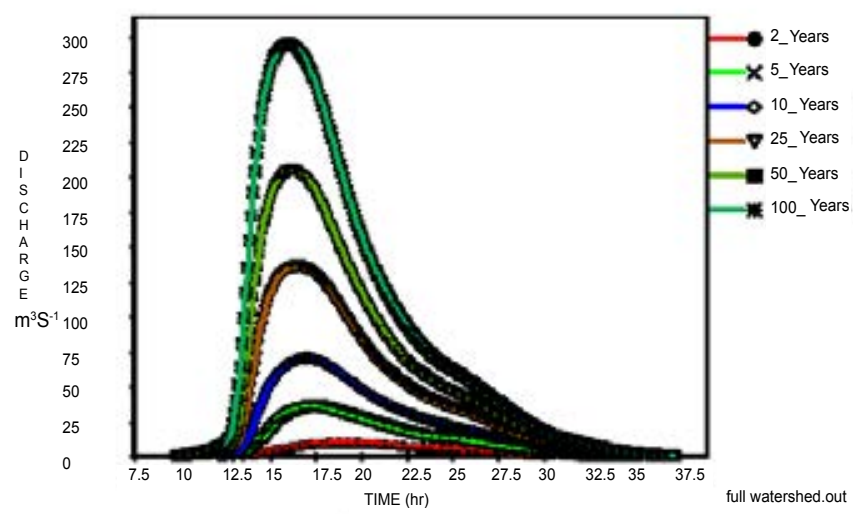

Figure 4: Predicted hydrographs generated through Win TR-20.

\section{References}

1. Pilgrim DH, Cordery I (1993) Flood runoff. In: Maidment DR (Ed.) Handbook of Hydrology. McGray-Hill, Inc, New York, pp. 9.1-9.42.

2. SCS (1983) Revised TR20: Computer Program for Project FormulationHydrology. USDA, Washington, DC.

3. Hagen VK (1995) Small urban watershed use of hydrologic procedures. Transport Res Rec 1471, 47-53.

4. Van Mullem JA (1991) Runoff and peak discharges using the Green-Ampt infiltration model. J Hydraul Eng 117: 354-370.

5. Fennessey LA, Hamlett JM, Aron G, Lasota D (2001a) Changes in runoff due to storm water management pond regulations. J Hydrol Eng ASCE 6: 317-327.

6. Fennessey LA, Miller AC, Hamlett JM (2001b) Accuracy and precision of NRCS models for small watersheds. J. Am. Water Resour Assoc 37: 899-912.

7. Mauser W (1984) Calculation of flood hydrographs using Landsat-derived landuse information in the Dreisam watershed in S-W Germany. Adv Space Res 4: 211- 216.

8. Barfield BJ, Felton GK, Stevens EW, McCann M (2004) A simple model of karst spring flow using modified NRCS procedures. J Hydrol 287: 34-48.

9. Cronshey RG, Woodward DE (2000) Computer program for project formulation: hydrology (TR-20) revisited. In: Fort Collins (ed) Watershed Management ASCE ConferenceProceedings, CO, USA, 20-24 June 2000 PL566, 16.

10. McCuen RH, Okunola O (2002) Extension of TR-55 for microwatersheds. J Hydrol Eng ASCE 7: 319-325.

11. Park CE (1994) Development of River flow forecasting model for the Youngsanestuary reservoir operation. Ph.D. thesis. Seoul National University, Seoul, Republic of Korea.

12. SCS (1972) National Engineering Handbook, Section 4, Hydrology. USDA, Washington, DC. 